\title{
In vitro digestibility of mountain-grown irrigated perennial legume, grass and forb forages is influenced by elevated non-fibrous carbohydrates and plant secondary compounds
}

Running title: Nutritive value and secondary compounds affect in vitro forage rumen digestibility

Yunhua Zhang†, Jennifer W. MacAdam*, Juan J. Villalba and Xin Dai

Correspondence to J.W. MacAdam, Department of Plants, Soils \& Climate, Utah State

University, Logan, Utah, 84322-4820, USA. Email: jennifer.macadam@usu.edu

Departments of Plants, Soils \& Climate and Wildland Resources, and Utah Agricultural Experiment Station, Utah State University, Logan, Utah, 84322, USA; †Y. Zhang, School of Resources and Environment, Anhui Agricultural University, Hefei, Anhui Province, 230036, P.R. China.

\begin{abstract}
BACKGROUND: Perennial legumes cultivated under irrigation in the Mountain West USA have non-fibrous carbohydrate (NFC) concentrations exceeding $400 \mathrm{~g} \mathrm{~kg}^{-1}$, a level commonly found in concentrate-based ruminant diets. Our objective was to determine the influence of NFC concentration and plant secondary compounds on in vitro rumen digestion of grass, legume and
\end{abstract}

This article has been accepted for publication and undergone full peer review but has not been through the copyediting, typesetting, pagination and proofreading process which may lead to differences between this version and the Version of Record. Please cite this article as doi: $10.1002 /$ jsfa. 10648 
forb forages compared with digestion of their isolated neutral detergent fiber (NDF) fraction. Forages were composited from ungrazed paddocks of rotationally stocked irrigated monoculture pastures between May and August 2016, frozen in the field, freeze-dried, and ground.

RESULTS: The maximum rate ( $\mathrm{R}_{\mathrm{Max}}$ ) of gas production was greater for the legumes alfalfa (ALF; Medicago sativa L.) and birdsfoot trefoil (BFT; Lotus corniculatus L.) than for the legume cicer milkvetch (CMV; Astragalus cicer L.) the grass meadow brome (MBG; Bromus riparius Rehm.) and the non-legume forb small burnet (SMB; Sanguisorba minor Scop.), and intermediate for the legume sainfoin (SNF; Onobrychis viciifolia Scop.). The RMax of isolated NDF was greatest for BFT and CMV, intermediate for ALF, SNF and SMB and least for MBG.

CONCLUSIONS: More than $900 \mathrm{~g}$ of organic matter (OM) kg-1 dry matter (DM) of legumes was digested after $96 \mathrm{~h}$. Across forages, the extent of whole plant digestion increased with NFC and crude protein (CP) concentrations, decreased with NDF concentrations, and was modulated by secondary compounds. The extent of digestion of isolated NDF decreased with concentration of lignin and residual tannins.

Keywords: condensed and hydrolysable tannins; cumulative fermentation gases; irrigated pastures; isolated fiber; non-fibrous carbohydrates; perennial legume forages 


\section{INTRODUCTION}

Increasing the forage content of beef finishing diets and dairy rations could reduce feed costs and improve the health and longevity of dairy cows ${ }^{1}$. Intake and digestibility of forages by ruminants are a function of forage neutral detergent fiber (NDF) and energy concentration ${ }^{2}$; however, the digestibility of NDF and the proportion of NDF that is ultimately not digested in the rumen ${ }^{3}$ can limit the rate of passage of forages from the rumen and thereby limit intake ${ }^{4}$. The concentration and biochemistry of lignin and the localization of its deposition in forage cell walls, constrains ruminant intake and digestibility ${ }^{5}$, while greater concentrations of non-fibrous carbohydrates (NFC) represent energy for microbial colonization of forages ${ }^{6}$. These variables are, in part, a function of plant phenology and environment ${ }^{7}$. For instance, forages grown under irrigation in the high-elevation Mountain West USA have more NFC and less NDF compared with the same forages cultivated in warmer, more humid environments ${ }^{8,9}$.

Legume forages such as the true clovers or alfalfa (ALF) are commonly grazed only as components of grass-legume mixtures to avoid issues with pasture bloat ${ }^{10}$ that can result from the rapid digestion of bloat-causing forages ${ }^{11}$. Temperate nutrient-dense legumes such as birdsfoot trefoil (BFT) and sainfoin (SNF) are non-bloating due to the presence of condensed tannins (CT) that precipitate excess plant protein in the rumen and reduce protein availability ${ }^{12}$, disrupt biofilms ${ }^{13}$, or alter rumen microbial ecology ${ }^{14}$. Alternatively, vein structural tissue holds the upper and lower epidermis of CMV leaves together ${ }^{15}$ preventing bloat by slowing rumen microbial access to plant cell contents. 
The objective of this study was to compare the rate and extent of digestion of two nontannin (ALF and CMV) and two CT-containing (BFT and SNF) legumes with a grass (MBG) and a non-legume forb (SMB) when these forages were grown under irrigation in the Mountain West region. Grasses have more fiber and less lignin than legumes ${ }^{5}$, and the non-legume forb SMB is persistent and palatable to livestock but contains a hydrolysable tannin (HT) that reduces

nitrogen excretion in the urine of beef cattle ${ }^{16}$. The in vitro gas production technique was used to study the influence of NDF, NFC, crude protein (CP), lignin, CT, HT and other nutrients and secondary plant compounds on the rumen digestibility of these forages.

\section{MATERIALS AND METHODS}

\section{Forage collection}

The six forage species used in this study were composited from irrigated monoculture pastures (0.365 ha each) that were rotationally stocked with dry beef cows from late May through midAugust of 2016. Pastures were located in Lewiston, Utah $\left(41.95^{\circ} \mathrm{N} ; 111.87^{\circ} \mathrm{W}\right.$; altitude 1370 m.a.s.l.). Composited material was collected weekly (CMV MBG and SMB; 11 dates x 5 reps; 1 g DM per sample) or monthly (ALF, BFT, SNF; 3 dates x 9 reps; 2 g DM per sample) between $8.00 \mathrm{~h}$ and $12.00 \mathrm{~h}$ from paddocks that would be grazed next in rotations by clipping 10 samples of each species to a $7.6 \mathrm{~cm}$ stubble. A total of approximately $250 \mathrm{~g}$ fresh weight was collected by walking a corner-to-corner transect of the paddock. Grass pasture regrowth was maintained in the vegetative stage and all forbs were maintained in the flowering stage during 
this period. Forage samples were immediately frozen under dry ice and stored at $-20^{\circ} \mathrm{C}$ until freeze-dried, then milled to pass the 1-mm screen of a Wiley mill (Thomas Scientific, Swedesboro, NJ, USA).

\section{NDF isolation}

Neutral detergent fiber of each species was isolated using the standard protocol for the ANKOM A200 Fiber Analyzer (ANKOM Technology, Macedon, NY, USA). Following an acetone rinse, samples were dried at $102^{\circ} \mathrm{C}$ and weighed to determine NDF concentration. Isolated NDF was soaked overnight in $10 \%(\mathrm{v} / \mathrm{v})$ tert-butyl alcohol and $90 \% 1 \mathrm{M}$ sodium sulfate at $39^{\circ} \mathrm{C}$ and rinsed successively with hot water, $95 \%$ ethanol, and acetone ${ }^{17}$ to remove traces of neutral detergent solution.

\section{In Vitro Rumen Fluid Fermentation}

The in vitro methodology of Theodorou et al. ${ }^{18}$ was used to determine the kinetics of rumen fermentation. Three runs of the fermentation were carried out over a 3-wk period. Triplicate samples of approximately $0.4 \mathrm{~g}$ of each whole plant and NDF isolate sample plus a BFT control and a blank were included in each run. Fermentations were carried out in 125-mL borosilicate glass serum bottles (Wheaton, Boston, MA, USA). A 40-mL aliquot of buffer containing macroand microminerals, artificial saliva, a reducing solution, and resazurin ${ }^{19}$ was added to forage in each bottle, which was flushed with $\mathrm{CO}_{2}$ and sealed with a butyl rubber septum and aluminum 
crimp cap (Wheaton). All reagents were purchased from Sigma-Aldrich (St. Louis, MO). Bottles with forage and buffer were stored overnight at $4^{\circ} \mathrm{C}$ then warmed to $39^{\circ} \mathrm{C}$ before $20 \mathrm{~mL}$ rumen fluid was added. Blank vials contained buffer and rumen fluid only.

Animal handling was conducted under Utah State University Institutional Animal Care and Use Committee protocol \#2834. Rumen fluid was collected approximately $4 \mathrm{~h}$ after a meal of ALF hay. Fluid was squeezed from the mat of fermenting forage of a ruminally cannulated Angus cow into a pre-warmed thermal flask, transported $15 \mathrm{~min}$. to the laboratory, strained twice through three layers of cheesecloth and maintained at $39^{\circ} \mathrm{C}$ under $\mathrm{CO}_{2}$ gas. The $\mathrm{pH}$ of rumen fluid was $6.3 \pm 0.4$. When fermentation was terminated at $96 \mathrm{~h}$, mean $\mathrm{pH}$ of all samples was 6.75 \pm 0.05 (SD); the $\mathrm{pH}$ of blanks was $7.02 \pm 0.20$, and the $\mathrm{pH}$ of controls was $6.92 \pm 0.08$.

Gas pressure measurements were made with a needle-equipped pressure transducer (PX409-015GUSBH; Omega Engineering Inc., Stamford, CT, USA) at 1, 2, 4, 6, 8, 10, 12, 18, 24, 36, 48, 72, and 96 hours after inoculation, and accumulated gas was vented after each measurement ${ }^{18}$. Fermentation was stopped by cooling serum bottles to $4^{\circ} \mathrm{C}$ in a walk-in freezer. Undigested fermentation residues were collected in ANKOM in situ bags with $50 \mu \mathrm{m}$ porosity, thoroughly rinsed with distilled water, and dried at $60^{\circ} \mathrm{C}$ to obtain dry mass.

Gas pressure was transformed to gas volume using the equation gas volume $(\mathrm{mL})=$ $5.3407 \times$ gas pressure $(\mathrm{psi})^{20}$. A single phasic model (Equation 1) for cumulative gas volume $(\mathrm{G})$ was used to calculate fermentation kinetics parameters where $\mathrm{A}$ ( $\mathrm{mL} \mathrm{g}^{-1}$ organic matter; $\mathrm{OM}$ ) was the asymptotic (maximum) gas volume, B (hours) was the incubation time $(t)$ at which half 
the maximum amount of gas had been formed, and $\mathrm{C}$ was a constant describing the sharpness of the switching characteristic of the cumulative gas curve ${ }^{21}$. As the value of C increases, cumulative gas production curves become more sigmoidal and increase in slope,

$G=\frac{A}{1+\left({ }^{B} / t^{C}\right.}$

Equation (1)

The time when the maximum rate of substrate digestion occurred $\left(t_{R_{M}}\right)$ and the maximum rate of substrate digestion $\left(R_{M a x}\right)$ were calculated from A, B, and and C using Equations 2 and $3^{21}$.

$t_{R_{M}}=B(C-1)^{1 / c}$

Equation (2)

$R_{\operatorname{Max}}=\frac{1}{B}(C-1)^{\left(1-\frac{1}{C}\right)}$

Equation (3)

\section{Forage Analyses}

Dry matter (DM) of forages and isolated fiber was determined by drying three subsamples of each forage for $48 \mathrm{~h}$ at $105^{\circ} \mathrm{C}$. Digestible dry matter (DDM) was calculated by subtracting DM of undigested fermentation residue at the end of the fermentation from substrate DM and dividing by substrate DM. Residues were ashed at $550^{\circ} \mathrm{C}$ and subtracted from substrate DM to estimate substrate OM. Undigested OM was calculated by subtracting ash from undigested fermentation residue DM; some minerals may have been solubilized during fermentation ${ }^{22}$. 
Digestible organic matter (DOM) was calculated by subtracting undigested OM from substrate $\mathrm{OM}$ and dividing by substrate $\mathrm{OM}$.

Forage composites were analyzed by near infrared spectroscopy (NIRS; FOSS 2500 Feed Analyser, Foss Analytics, Hilleroed, Denmark) to estimate CP, amylase-treated NDF (aNDF), NDF digestibility as a proportion of NDF (NDFD), acid detergent fiber (ADF), NFC, ash, acid detergent lignin (ADL), fat, and total digestible nutrients (TDN) using the March 2018 NIRS Consortium mixed hay equation (https://www.nirsconsortium.org/). The calibration set for this equation does not include SMB. The WSC concentration of forage samples was determined by the phenol-sulfuric acid method ${ }^{23}$, and their starch concentration by the glucose oxidaseperoxidase method ${ }^{24}$.

Total CT concentrations were determined by the butanol-HCl-acetone method ${ }^{25}$. Condensed tannin standards were isolated from BFT and SNF ${ }^{26}$. Hydrolyzable tannins were determined for SMB relative to methyl gallate standards and a tannic acid check ${ }^{27}$.

\section{Experimental Design and Statistical Analyses}

Cumulative fermentation gas kinetics parameters were estimated using PROC NLIN and then analyzed using PROC GLIMMIX (SAS/STAT 14.3, SAS Institute Inc., Cary, NC, USA) with a mixed model in which run was the random factor, and species and material (whole plant or isolated fiber) with their interaction were fixed effects. To account for the correlation of whole plant and isolated fiber materials from the same species, a heterogeneous compound-symmetry 
structure (CSH) was included based on AIC and BIC selection. Pairwise differences among the least squares means (LSMEANS) of the kinetics parameters were tested with Tukey-Kramer multiplicity adjustment. PROC CORR was used to determine correlation between whole plant DDM and CP and between ADL and undigested OM. Tests were considered significant at the 0.05 level.

\section{RESULTS}

The four legumes used in this study (ALF, BFT, CMV, and SNF) had similar CP, NDF and NFC concentrations (Table 1). The mean CP concentrations of these legumes was approximately twice that of the grass and the non-legume forb, and their NDF concentrations were approximately half that of the grass and the forb (Table 1). The NFC concentration of the nonlegume forb was similar to legume NFC concentrations, and the NFC concentrations of all five forbs was more than twice that of the grass (Table 1). Acid detergent lignin concentrations were similar for three of the legumes (ALF, BFT, and CMV), while ADL values were similar for SNF and SMB; the four legumes and the non-legume forb had ADL values 1.4 to 2 times greater than that of the grass. Neutral detergent fiber concentrations estimated by NIRS (Table 1) and NDF concentrations determined by ANKOM digestion (Table 2) were ranked similarly, including that of SMB. Values for NDF by NIRS averaged 7\% less than ANKOM analysis.

Water-soluble carbohydrate (WSC) concentrations (Table 2) were greatest for the legumes BFT and CMV and the forb SMB, and were greater for the legume SNF than the grass. 
The WSC concentration of ALF was less than that of other forages tested, while starch concentration was greatest for ALF. In whole plant material, the CT concentration of SNF was more than double that of BFT, and the concentration of $\mathrm{HT}$ in SMB was intermediate to the CT concentrations of BFT and SNF (Table 2). Isolated NDF of SMB retained about half the HT concentration of whole plant material, while isolated NDF of BFT and SNF retained 28 and $21 \%$, respectively, of the CT in whole plant material of these species (Table 2).

Whole plant DDM and DOM did not differ among legumes and were greater than for the grass; grass values were greater than the non-legume forb SMB (Table 3). There was a positive correlation between whole plant DDM and CP ( $r=0.94$;). The concentrations of undigested OM for whole plant material of MBG and SMB were approximately two and three times greater, respectively, than that of the four legumes (Table 3).

The DDM of isolated NDF was greatest for CMV followed by the grass, and least for SMB (Table 3). Acid detergent lignin concentration was positively correlated with undigested OM of isolated NDF ( $r=0.86)$. For isolated NDF, more OM remained undigested for the three tannin-containing forages than for other forage species. The NDF of SMB contained the greatest concentration of HT and had the greatest concentration of undigested OM, followed by SNF and BFT.

Forage species had a significant effect on RMax (Table 4) of both whole plant material and isolated NDF. The RMax of ALF and BFT was greater than for other forages except SNF, and the RMax of isolated NDF was greater for BFT and CMV than MBG. Time to reach RMax $\left(t_{R_{M}}\right)$ was 
less than $8 \mathrm{~h}$ for whole plant material of all species and more than $28 \mathrm{~h}$ for isolated NDF of all species (Table 4). The RMax of isolated NDF reached values equal to or greater than the rate observed for whole plant material of CMV, MBG, and SMB.

The asymptotic gas volume (Parameter $\mathrm{A}$ ) is the cumulative gas production at the end of fermentation predicted from analysis of cumulative gas as a function of time (Fig. 1). Asymptotic gas volume of MBG whole plant material was greater than that of CMV and SMB whole plant material, and did not differ from that of ALF, BFT, and SNF whole plant material (Table 5). Asymptotic gas volume of isolated NDF was greatest for CMV and MBG and least for SMB. Acid detergent lignin concentration was negatively correlated with asymptotic gas volume of isolated NDF $(r=-0.93)$.

Hours to one-half asymptotic cumulative gas volume (Parameter B; Table 5) is related to both the rate and extent of fermentation; a lower value for Parameter B reflects a more rapid rate of rumen digestion. Among whole plant material, time to one-half gas volume was greatest for MBG and SMB, and did not differ from that of CMV. Parameter B of whole plant CMV did not differ from SNF, and Parameter B of whole plant SNF did not differ from ALF and BFT, which reached one-half asymptotic cumulative gas volume the most quickly; ALF and BFT also had the greatest whole plant $\mathrm{R}_{\mathrm{MAX}}$. Time to one-half asymptotic gas volume of whole plant material was negatively correlated with CP $(r=-0.90)$. For isolated NDF, time to one-half asymptotic cumulative gas volume was greater for MBG than for ALF, BFT, and CMV and did not differ from SNF and SMB (Table 5). 
For whole plant material, Parameter C was greater for ALF and BFT than for CMV, MBG, and SMB indicating a sharper acceleration of fermentation rate following the initial lag phase. Parameter C was greater for whole plant SNF than MBG and SMB and did not differ from ALF, BFT or CMV (Table 5). Values of Parameter C (Table 5) were greater for isolated NDF than for whole plant material ( $p<0.01$ ) and did not differ among forages (Fig. 1).

\section{DISCUSSION}

The NFC concentrations of legumes grown in the Mountain West were comparable to those for corn silage (358 $\left.\mathrm{g} \mathrm{kg}^{-1} \mathrm{DM}\right)$ and beet pulp $\left(383 \mathrm{~g} \mathrm{~kg}^{-1} \mathrm{DM}\right)^{28}$. The elevated NFC concentrations of forages cultivated in the Mountain West likely result from the greater net photosynthesis of long, sunny days ${ }^{29}$ combined with cool night temperatures that reduce the rate of respiration that consumes non-structural carbohydrates ${ }^{30}$.

Starch concentration was least in the cool-season grass, which stores carbohydrates as fructans ${ }^{31}$ in leaf and stem bases below grazing height. Alfalfa starch concentration in this study was greater than values generally reported for forage legumes; however, starch concentration of red clover (Trifolium pretense L.) leaves reached $350 \mathrm{~g} \mathrm{~kg}^{-1} \mathrm{DM}$ by the end of the day when grown at day/night temperatures of $19-23^{\circ} \mathrm{C} / 14-16^{\circ} \mathrm{C}^{32}$. When legume WSC and starch concentrations were summed by species, they accounted for $27 \%$ (CMV) to $46 \%$ (ALF) of NFC; the balance of NFC consists of organic acids and ND-soluble fiber, including pectins and some hemicelluloses ${ }^{33}$. 
Increasing the NFC of high-forage diets by adding grain usually decreases fiber digestibility ${ }^{34}$, augmentes VFA synthesis and may increase nutrient flow from the rumen ${ }^{35,36}$. In this study, the undigested OM of isolated legume NDF ranged from 225 to $503 \mathrm{~g} \mathrm{~kg}^{-1} \mathrm{DM}$ after $96 \mathrm{~h}$ while legume whole plant undigested OM ranged from 78 to $88 \mathrm{~g} \mathrm{~kg}^{-1} \mathrm{DM}$. The whole plant undigested OM of SMB, the non-legume forb, was nearly three times greater than for the legumes even though NFC of all five forbs was similar. The reduced digestibility of SMB whole plant and isolated fiber was likely due to the antimicrobial activity of HT, which is known to negatively affect digestion ${ }^{37}$. These results demonstrate that NFC does not inhibit NDF digestion, and that the extent of forage digestion is influenced by the concentration of NDF and can be modulated by the presence of plant secondary compounds in NDF. Whole plant 96-h DDM of the tannin-containing legumes BFT and SNF was similar to the non-tannin legumes ALF and CMV.

Grass whole plant material produced the greatest asymptotic fermentation gas volume (Parameter A). Diets with greater fiber concentrations result in greater rumen acetate-topropionate ratios $^{38}$, and acetate synthesis results in a greater volume of gas production than propionate synthesis ${ }^{39,40}$. Comparing the gas volume of isolated forage NDF eliminates variation due to acetate and propionate contributions, since non-structural carbohydrates are the main source of propionate synthesis. Cicer milkvetch contains a water-soluble arabinogalactan protein that prevents cellulolytic bacteria from digesting cellulose ${ }^{41,42}$ and cattle gained significantly less on irrigated, rotationally stocked CMV than BFT pastures ${ }^{43}$. This 
arabinogalactan protein may account for the lower $\mathrm{R}_{\text {Max }}$ and greater Parameter $\mathrm{B}$ of whole plant CMV that suggests inhibited short-term digestion compared with ALF and BFT. However, these parameters were not less for CMV isolated fiber. While ALF and CMV had similar whole plant ADL concentrations, ALF has more rigid, erect stems while CMV has less rigid, vine-like stems. These differences in stem structure could result from differences in the amount, type or localization of lignin in stem fiber cell walls ${ }^{44}$ and result in greater isolated NDF DDM of CMV compared with ALF. The grass had the least ADL, which was positively correlated with undigested NDF OM and negatively correlated with isolated NDF asymptotic gas volume. The extent of digestion of SMB isolated NDF was likely constrained by both elevated ADL and the presence of about 50\% whole plant HT retained in isolated NDF.

More OM remained undigested in NDF isolates from tanniferous species that retained tannins in the NDF fraction. The HT in SMB bound more dietary N than the CT in BFT or SNF when beef cows were fed tannin-containing hays as their complete diet ${ }^{16}$. Here, the NDF of SMB, with half the whole-plant concentration of HT, had the greatest undigested OM. Tannins may bind to structural cell wall proteins and inhibit enzymes secreted by wall-digesting rumen microbes. The concentration of structural proteins in monocots is approximately $1 \%$ while structural proteins comprise as much as $10 \%$ of the cell walls of dicots, including legumes and forbs ${ }^{45}$. Our demonstration that the NDF fraction of tanniferous forages retains significant CT and HT concentrations suggests tannins could influence the digestion of both the cell contents and the cell wall fraction of forages. 


\section{CONCLUSIONS}

The perennial legumes used in this study had elevated whole plant CP compared with the grass MBG and the forb SMB. The four legumes and the forb, SMB, had elevated NFC concentrations compared with the grass. The four legumes had the greatest DDM and DOM of the six forages, and the least undigested OM after $96 \mathrm{~h}$. The digestion of isolated NDF, however, was more variable and reduced by the combined concentratons of lignin and residual tannin. Among the legumes, ALF and BFT had similarly elevated maximal rates of digestion, abbreviated times to one-half asymptotic cumulative gas production, and sharp inflection points in their cumulative gas curves. While the CT concentrations of BFT and SNF appeared to affect isolated NDF digestion, they did not reduce the extent of forage digestion measured as DDM. However, some combination of reduced protein concentration, elevated NDF and the presence of HT inhibited both the rate and extent of SMB digestion. While the fiber of CMV was rapidly and more completely digested than that of other forage species, the digestion of CMV whole plant material was extensive but less rapid than other legumes, perhaps due to the presence of a water-soluble arabinogalactan that inhibits fiber digestion. Reducing the concentration of secondary compounds such as the arabinogalactan in CMV or the HT in SMB would be worthy plant breeding goals to enhance forage digestibility and improve the nutrition and productivity of ruminants grazing these forages. 


\section{CONFLICT OF INTEREST}

The authors have no conflict of interest that might have influenced this study.

\section{ACKNOWLEDGEMENTS}

This research was supported by National Natural Science Foundation of China grant 31872418 and by the Utah Agricultural Experiment Station, Utah State University, and approved as journal paper number 9167. We thank Dr. Jim Pfister and Kermit Price for assistance with NDF isolation, and Casey Spackman and Clint Stonecipher for assistance with the fermentation study and rumen fluid collection. We also thank Dr. Mary Beth Hall for guidance on WSC and starch analysis of forages. 


\section{REFERENCES}

1. Chase LE and Grant RJ, High forage rations - What do we know?, in Proceedings of the 75th Cornell Nutrition Conference for Feed Manufacturers, Ed. Cornell Univ., Ithaca, NY, East Syracuse, NY, pp 203-209 (2013).

2. Mertens DR, Predicting intake and digestibility using mathematical models of ruminal function. Journal of Aminal Science 64:1548-1558 (1987).

3. Cotanch KW, Grant RJ, Van Amburgh ME, Zontini A, Fustini M, Palmonari A and Formigoni A, Applications of uNDF in ration modeling and formulation, in Proceedings of the 76th Cornell Nutrition Conference for Feed Manufacturers, Ed. Cornell Univ., Ithaca, NY, East Syracuse, NY, pp 141-131 (2014).

4. Mertens DR, Maximizing forage use by dairy cows, in Proceedings of the Western Canadian Dairy Seminar, Ed, Red Deer, Alberta, Canada (2009).

5. Jung HG and Allen MS, Characteristics of plant cell walls affecting intake and digestibility of forages by ruminants. Journal of Animal Science 73:2774-2790 (1995).

6. Van Soest PJ, Nutritional Ecology of the Ruminant. Cornell University Press, Ithaca, NY (1994).

7. Van Soest PJ, Mertens DR and Deinum B, Preharvest factors influencing quality of conserved forage. Journal of Animal Science 47:712-720 (1978).

8. Wen L, Kallenbach, R. L., Williams, J. E., Roberts, C. A., Beuselinck, P. R., McGraw, R. L., and Benedict, H. R., Performance of steers grazing rhizomatous and nonrhizomatous birdsfoot trefoil in pure stands and in tall fescue mixtures. Journal of Animal Science 80:19701976 (2002).

9. Nie Z, Tremblay GF, Bélanger G, Berthiaume R, Castonguay Y, Bertrand A, Michaud R, Allard G and Han J, Near-infrared reflectance spectroscopy prediction of neutral detergentsoluble carbohydrates in timothy and alfalfa. Journal of Dairy Science 92:1702-1711 (2009). 10. Phelan P, Moloney AP, McGeough EJ, Humphreys J, Bertilsson J, O’Riordan EG and O’Kiely P, Forage legumes for grazing and conserving in ruminant production systems. Critical Reviews in Plant Science 34:281-326 (2015).

11. Howarth RE, Chaplin, R.K., Cheng, K.-J., Boplen, B.P., Hall, J.W., Hironaka, R., Majak, W., and Radostits, O.M., Bloat in Cattle, Ed. Agriculture Canada, Ottawa (1991).

12. Jones WT and Mangan JL, Complexes of the condensed tannins of sainfoin (Onobrychis viciifolia Scop.) with Fraction 1 leaf protein and with submaxillary mucoprotein, and their reversal by polyethylene glycol and pH. Journal of the Science of Food and Agriculture 28:126136 (1977).

13. Min BR, Pinchak WE, Anderson RC, Fulford JD and Puchala R, Effects of condensed tannins supplementation level on weight gain and in vitro and in vivo bloat precursors in steers grazing winter wheat. Journal of Animal Science 84:2546-2554 (2006). 
14. McSweeney CS, Palmer B, McNeill DM and Krause DO, Microbial interactions with tannins: Nutritional consequences for ruminants. Animal Feed Science and Technology 91:83-93 (2001).

15. Lees GL, Howarth RE and Goplen BP, Morphological characteristics of leaves from some legume forages: Relation to digestion and mechanical strength. Canadian Journal of Botany 60:2126-2132 (1982).

16. Stewart EK, Beauchemin KA, Dai X, MacAdam JW, Christensen RG and Villalba JJ, Effect of tannin-containing hays on enteric methane emissions and nitrogen partitioning in beef cattle. Journal of Animal Science 97:3286-3299 (2019).

17. Doane PH, Schofield P and Pell AN, Neutral detergent fiber disappearance and gas and volatile fatty acid production during the in vitro fermentation of six forages. Journal of Animal Science 75:3342-3352 (1997).

18. Theodorou MK, Williams BA, Dhanoa MS, McAllan AB and France J, A simple gas production method using a pressure transducer to determine the fermentation kinetics of ruminant feeds. Animal Feed Science and Technology 48:185-197 (1994).

19. Menke KH and Steingass $\mathrm{H}$, Estimation of the energetic feed value from chemical analysis and in vitro gas production using rumen fluid. Animal Research and Development 28:755 (1988).

20. Frutos P, Hervás G, Ramos G, Giráldez FJ and R. MA, Condensed tannin content of several shrub species from a mountain area in northern Spain, and its relationship to various indicators of nutritive value. Animal Feed Science and Technology 95:215-226 (2002 ).

21. Groot JCJ, Cone JW, Williams BA, Debersaques FMA and Lantinga EA, Multiphasic analysis of gas production kinetics for in vitro fermentation of ruminant feeds. Animal Feed Science and Technology 64:77-89 (1996).

22. Emanuele SM, Staples CR and Wilcox CJ, Extent and site of mineral release from six forage species incubated in mobile dacron bags. Journal of Animal Science 69:801-810 (1991). 23. Dubois M, Gilles KA, Hamilton JK, Rebers PA and Smith F, Colorimetric method for determination of sugars and related substances. Analytical Chemistry 28:350-356 (1956).

24. Karkalas J, An improved enzymic method for the determination of native and modified starch. Journal of the Science of Food and Agriculture 36:1019-1027 (1985).

25. Grabber JH, Zeller WE and Mueller-Harvey I, Acetone enhances the direct analysis of procyanidin and prodelphinidin-based condensed tannins in Lotus species by the butanol-HCl-iron assay. Journal of Agricultural and Food Chemistry 61:2669-2678 (2013). 26. Hagerman AE, Extraction of phenolics from plants, Sephadex LH 20 and separation of tannin from non-tannin phenolics. The Tannin Handbook, Ed (2011).

27. Hartzfeld PW, Forkner R, Hunter MD and Hagerman AE, Determination of hydrolyzable tannins (gallotannins and ellagitannins) after reaction with potassium iodate. Journal of Agricultural and Food Chemistry 50:1785-1790 (2002). 
28. Getachew G, Robinson PH, DePeters EJ and J. TS, Relationships between chemical composition, dry matter degradation and in vitro gas production of several ruminant feeds. Animal Feed Science and Technology 111:57-71 (2004).

29. Ku SB and Hunt LA, Effects of temperature on the photosynthesis-irradiance response curves of newly matured leaves of alfalfa. Canadian Journal of Botany 55:872-879 (1977).

30. P. Jing DW, C. Zhu, J. Chen, Plant physiological, morphological and yield-related responses to night temperature changes across different species and plant functional types. Frontiers in Plant Science 7:1774 (2016).

31. Ojima $\mathrm{K}$ and Isawa $\mathrm{T}$, The variation of carbohydrates in various species of grasses and legumes. Canadian Journal of Botany 46:1507-1511 (1968).

32. Ruckle ME, Meier MA, Frey L, Eicke S, R. K, Zeeman SC and Studer B, Diurnal leaf starch content: An orphan trait in forage legumes. Agronomy 7 (2017).

33. Hall MB, Challenges with nonfiber carbohydrate methods. Journal of Animal Science 81:3226-3232 (2003).

34. Mertens DR, Creating a system for meeting the fiber requirements of dairy cows. Journal of Dairy Science 80:1463-1481 (1997).

35. Aguerre M, Cajarville C, Kozloski GV and Repetto JL, Intake and digestive responses by ruminants fed fresh temperate pasture supplemented with increased levels of sorghum grain: A comparison between cattle and sheep. Animal Feed Science and Technology 186:12-19 (2013).

36. Ma T, Tu Y, Zhang NF, Deng KD and Diao QY, Effect of the ratio of non-fibrous carbohydrates to neutral detergent fiber and protein structure on intake, digestibility, rumen fermentation, and nitrogen metabolism in lambs. Asian Australasian Journal of Animal Science 28:1419-1426 (2015).

37. Ekambaram SP, Perumal SS and Balakrishnan A, Scope of hydrolysable tannins as possible antimicrobial agent. Phytotherapy Research 30:1035-1045 (2016).

38. Sarwar M, Firkins JL and Eastridge ML, Effects of varying forage and concentrate carbohydrates on nutrient digestibilities and milk production by dairy cows. Journal of Dairy Science 75:1533-1542 (1992).

39. Wolin MJ, A theoretical rumen fermentation balance. Journal of Dairy Science 43:14521459 (1960).

40. Blümmel M, Makkar HPS and Becker K, In vitro gas production: a technique revisited. Journal of Animal Physiology and Animal Nutrition 77:24-34 (1997).

41. Weimer PJ, Hatfield RD and Buxton DR, Inhibition of ruminal cellulose fermentation by extracts of the perennial legume cicer milkvetch (Astragalus cicer). Applied and Environmental Microbiology 59:405-409 (1993).

42. Weimer PJ, Manipulating ruminal fermentation: A microbial ecological perspective. Journal of Animal Science 76:3114-3122 (1998).

43. Pitcher LR, Beef Average Daily Gain and Enteric Methane Emissions on Birdsfoot Trefoil, Cicer Milkvetch and Meadow Brome Pastures, Ed. Utah State University, Logan, Utah, USA (2015). 
44. Hunt SR, MacAdam JW and Griggs TC, Lignification and tannin localization during the development of birdsfoot trefoil stems. Crop Science 54:1876-1886 (2014).

45. Vogel J, Unique aspects of the grass cell wall. Current Opinion in Plant Biology 11:301307 (2008). 


\section{Figure Legend}

Fig. 1. Cumulative gas production of whole plant material (A) and isolated neutral detergent fiber (B) for an in vitro fermentation carried out for $96 \mathrm{~h}$, expressed as $\mathrm{mL}$ gas g $^{-1}$ digestible organic matter (DOM). Error bars represent SEM; $\mathrm{n}=3$. 
Table 1. Near infrared spectroscopy (NIRS) predictions of for nutritive value composited from pre-grazed rotationally stocked irrigated pastures from May through August of 2016.

\begin{tabular}{|c|c|c|c|c|c|c|c|c|c|}
\hline & $\mathrm{CP}$ & $\mathrm{ADF}$ & aNDF & NDFD & NFC & Ash & $\mathrm{ADL}$ & Fat & TDN \\
\hline Species & \multicolumn{3}{|c|}{-----g kg-1 DM----- } & $\mathrm{g} \mathrm{kg}^{-1} \mathrm{NDF}$ & \multicolumn{5}{|c|}{--------g kg-1 DM-------- } \\
\hline ALF & 259 & 198 & 226 & 515 & 441 & 68.9 & 50.8 & 14.5 & 700 \\
\hline BFT & 259 & 179 & 192 & 373 & 481 & 62.9 & 54.2 & 16.0 & 822 \\
\hline CMV & 253 & 212 & 238 & 671 & 424 & 80.2 & 50.8 & 14.8 & 784 \\
\hline SNF & 218 & 233 & 252 & 320 & 476 & 48.8 & 73.1 & 07.0 & 760 \\
\hline MBG & 136 & 370 & 588 & 618 & 190 & 80.3 & 36.8 & 27.9 & 604 \\
\hline SMB & 122 & 298 & 412 & 487 & 401 & 59.8 & 77.4 & 34.7 & 686 \\
\hline
\end{tabular}

$\mathrm{CP}$, crude protein; ADF, acid detergent fiber; aNDF, neutral detergent fiber assayed with a heatstable $\alpha$-amylase; NDFD, NDF digestibility; NFC, non-fibrous carbohydrates; ADL, acid detergent lignin; TDN, total digestible nutrients.

ALF, alfalfa; BFT, birdsfoot trefoil; CMV, cicer milkvetch; SNF, sainfoin; MBG, meadow bromegrass; SMB, small burnet.

NIRS Consortium calibration equations do not include small burnet. 
Table 2. Fiber, carbohydrate and tannin concentrations of whole plant material and tannin concentrations of isolated neutral detergent fiber (NDF) of forages composited from pre-grazed rotationally stocked irrigated pastures from May through August of 2016.

\begin{tabular}{|c|c|c|c|c|c|}
\hline \multirow[t]{2}{*}{ Species } & $\begin{array}{c}\text { ANKOM aNDF } \\
(\mathrm{SE})\end{array}$ & $\begin{array}{l}\text { WSC } \\
\text { (SD) }\end{array}$ & $\begin{array}{l}\text { Starch } \\
\text { (SD) }\end{array}$ & $\begin{array}{l}\text { Whole Plant Tannins } \\
\text { (SD) }\end{array}$ & $\begin{array}{l}\text { NDF Tannins } \\
\text { (SD) }\end{array}$ \\
\hline & \multicolumn{5}{|c|}{ - } \\
\hline ALF & 260d (0.29) & $\begin{array}{l}86.5 d \\
(1.36)\end{array}$ & $\begin{array}{c}67.0 \mathrm{a} \\
(0.26)\end{array}$ & & \\
\hline BFT & 245e (0.27) & $\begin{array}{c}125.9 \mathrm{a} \\
(4.20)\end{array}$ & $\begin{array}{l}36.5 b \\
(0.17)\end{array}$ & 21.2c (1.86) & 6.0c (0.41) \\
\hline CMV & 261d (0.15) & $\begin{array}{l}130.1 \mathrm{a} \\
(2.01)\end{array}$ & $\begin{array}{l}15.3 d \\
(0.44)\end{array}$ & & \\
\hline SNF & 300c (0.24) & $\begin{array}{c}110.1 \mathrm{~b} \\
(7.28)\end{array}$ & $\begin{array}{l}31.8 \mathrm{c} \\
(0.10)\end{array}$ & 56.1a (2.07) & $11.8 \mathrm{~b}(0.19)$ \\
\hline MBG & 577a (0.07) & $\begin{array}{c}92.3 c \\
(4.54)\end{array}$ & $\begin{array}{c}8.0 \mathrm{e} \\
(0.30)\end{array}$ & & \\
\hline SMB & 406b (0.23) & $\begin{array}{c}131.1 \mathrm{a} \\
(5.44)\end{array}$ & $\begin{array}{l}14.0 \mathrm{~d} \\
(1.57)\end{array}$ & 39.6b (1.28) & 19.9a (1.28) \\
\hline
\end{tabular}

ALF, alfalfa; BFT, birdsfoot trefoil; CMV, cicer milkvetch; MBG, meadow bromegrass; SMB, small burnet; SNF, sainfoin.

For neutral detergent fiber (aNDF), grass $n=46$ and forb $n=69$; aNDF values followed by the same letter are not different at $p<0.05$ based on the Tukey-Kramer multiplicity adjustment. Water-soluble carbohydrate (WSC), starch and tannin data are the means of three laboratory replicates. ALF, CMV and MBG contain no condensed or hydrolyzable tannins. 
Table 3. Characteristics of whole plant and isolated neutral detergent fiber (NDF) of forages composited from pre-grazed rotationally stocked irrigated pastures from May through August of 2016. Data are the means of three laboratory runs; standard errors in parentheses.

\begin{tabular}{|c|c|c|c|c|c|c|}
\hline \multirow[b]{2}{*}{ Species } & \multicolumn{3}{|c|}{ Whole Plant Material } & \multicolumn{3}{|c|}{ Isolated NDF } \\
\hline & DDM & DOM & $\begin{array}{c}\text { Undigested } \\
\text { OM }\end{array}$ & $\begin{array}{l}\text { NDF } \\
\text { DDM }\end{array}$ & $\begin{array}{l}\text { NDF } \\
\text { DOM }\end{array}$ & $\begin{array}{c}\text { NDF Undigested } \\
\text { OM }\end{array}$ \\
\hline & & & & & & \\
\hline ALF & $\begin{array}{l}833 a \\
(9.6)\end{array}$ & $\begin{array}{l}917 \mathrm{a} \\
(6.7)\end{array}$ & 80c (6.4) & $\begin{array}{l}626 c \\
(9.6)\end{array}$ & $\begin{array}{l}684 b \\
(6.7)\end{array}$ & 306с (13.8) \\
\hline BFT & $\begin{array}{c}831 a \\
(14.0)\end{array}$ & $\begin{array}{c}916 \mathrm{a} \\
(11.3)\end{array}$ & 82c (6.4) & $\begin{array}{c}467 d \\
(14.0)\end{array}$ & $\begin{array}{c}532 \mathrm{c} \\
(11.3)\end{array}$ & 451b (13.8) \\
\hline CMV & $\begin{array}{l}852 a \\
(7.4)\end{array}$ & $\begin{array}{l}918 a \\
(7.4)\end{array}$ & $78 c(6.4)$ & $\begin{array}{l}720 \mathrm{a} \\
(7.4)\end{array}$ & $\begin{array}{l}764 a \\
(7.4)\end{array}$ & 225d (13.8) \\
\hline SNF & $\begin{array}{l}848 a \\
(13.6)\end{array}$ & $\begin{array}{l}908 a \\
(9.7)\end{array}$ & $88 c(6.4)$ & $\begin{array}{l}432 d \\
(13.6)\end{array}$ & $\begin{array}{l}478 d \\
(9.7)\end{array}$ & 503b (13.8) \\
\hline MBG & $\begin{array}{l}738 b \\
(8.2)\end{array}$ & $\begin{array}{l}796 \mathrm{~b} \\
(5.8)\end{array}$ & 198b (6.4) & $\begin{array}{l}669 b \\
(8.2)\end{array}$ & $\begin{array}{l}706 \mathrm{~b} \\
(5.8)\end{array}$ & 281cd (13.8) \\
\hline SMB & $\begin{array}{l}693 c \\
(9.2)\end{array}$ & $\begin{array}{l}758 c \\
(8.0)\end{array}$ & 235a (6.4) & $\begin{array}{l}347 e \\
(9.2)\end{array}$ & $\begin{array}{l}408 \mathrm{e} \\
(8.0)\end{array}$ & 573a (13.8) \\
\hline
\end{tabular}

DDM, digestible dry matter; DOM, digestible organic matter; OM, organic matter.

ALF, alfalfa; BFT, birdsfoot trefoil; CMV, cicer milkvetch; SNF, sainfoin; MBG, meadow bromegrass; SMB, small burnet.

Values within a column followed by the same letter are not different at $p<0.05$ based on the Tukey-Kramer multiplicity adjustment. 
Table 4. Maximum rate ( $\left.\mathrm{R}_{\mathrm{Max}}\right)$ and time during fermentation at which maximum rate of cumulative gas production is reached $\left(t_{R_{M}}\right)$ based on in vitro fermentation of whole plant and isolated neutral detergent fiber (NDF) expressed on an organic matter (OM) basis.

\begin{tabular}{|c|c|c|c|c|c|c|}
\hline \multirow[t]{3}{*}{ Species } & ALF & BFT & CMV & SNF & MBG & SMB \\
\hline & \multicolumn{6}{|c|}{$\mathrm{R}_{\text {Max }}$} \\
\hline & --------------- & - & 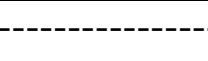 & $-\mathrm{mL}$ gas $\mathrm{g}^{-1}$ & $\mathrm{M} \mathrm{h}^{-1}$ & ---------------' \\
\hline Whole & $\begin{array}{c}0.071 \mathrm{a} \\
(0.0052)\end{array}$ & $\begin{array}{c}0.072 \mathrm{a} \\
(0.0052)\end{array}$ & $\begin{array}{c}0.040 \mathrm{~b} \\
(0.0052)\end{array}$ & $\begin{array}{c}0.053 \mathrm{ab} \\
(0.0052)\end{array}$ & $\begin{array}{c}0.032 \mathrm{~b} \\
(0.0052)\end{array}$ & $\begin{array}{c}0.034 b \\
(0.0052)\end{array}$ \\
\hline \multirow[t]{3}{*}{ NDF } & $\begin{array}{l}0.046 a b \\
(0.0022)\end{array}$ & $\begin{array}{c}0.052 \mathrm{a} \\
(0.0022)\end{array}$ & $\begin{array}{c}0.052 \mathrm{a} \\
(0.0022)\end{array}$ & $\begin{array}{l}0.047 \mathrm{ab} \\
(0.0022)\end{array}$ & $\begin{array}{c}0.040 \mathrm{~b} \\
(0.0022)\end{array}$ & $\begin{array}{l}0.044 a b \\
(0.0022)\end{array}$ \\
\hline & \multicolumn{6}{|c|}{$t_{R_{M}}$} \\
\hline & & & & $\cdots$ & & \\
\hline Whole & $7.3(2.23)$ & 6.7 (2.23) & $7.2(2.23)$ & 7.7 (2.23) & $7.7(2.25)$ & $3.4(2.23)$ \\
\hline NDF & $28.5(2.41)$ & 30.4 (2.41) & $30.4(2.41)$ & $33.0(2.41)$ & 33.7 (2.41) & 31.7 (2.41) \\
\hline
\end{tabular}

ALF, alfalfa; BFT, birdsfoot trefoil; CMV, cicer milkvetch; SNF, sainfoin; MBG, meadow bromegrass; SMB, small burnet.

Data are the means of three laboratory runs and three replicates in each run; standard errors in parentheses.

Values within a row followed by the same letter are not different at $p<0.05$ based on the TukeyKramer multiplicity adjustment. 
Table 5. Kinetics of cumulative gas production from in vitro fermentation of whole plant and isolated neutral detergent fiber (NDF) ${ }^{21}$. Parameters include asymptotic cumulative gas production (A) expressed on an organic matter (OM) basis, time to one-half asymptotic cumulative gas volume (B), and a constant (C) describing the sharpness of the sigmoidal inflection point.

\begin{tabular}{|c|c|c|c|c|c|c|}
\hline \multirow[t]{3}{*}{ Species } & ALF & BFT & CMV & SNF & MBG & SMB \\
\hline & \multicolumn{6}{|c|}{ Parameter A } \\
\hline & & & $\mathrm{mL} \mathrm{g}$ & ${ }^{1} \mathrm{OM}$ & & \\
\hline Whole & $\begin{array}{l}\text { 194ab } \\
(13.5)\end{array}$ & $\begin{array}{l}\text { 187ab } \\
(13.0)\end{array}$ & $162 \mathrm{~b}(11.3)$ & $\begin{array}{l}\text { 171ab } \\
\text { (11.9) }\end{array}$ & 207a (14.4) & 164b (11.4) \\
\hline \multirow[t]{3}{*}{ NDF } & $164 b(8.6)$ & $152 b(7.9)$ & 188a (9.8) & $123 c(6.4)$ & 181a (9.4) & 104d (5.4) \\
\hline & \multicolumn{6}{|c|}{ Parameter B } \\
\hline & \multicolumn{6}{|c|}{ hour } \\
\hline Whole & $\begin{array}{l}12.4 \mathrm{C} \\
(1.34)\end{array}$ & $\begin{array}{c}12.2 \mathrm{c} \\
(1.32)\end{array}$ & $\begin{array}{l}20.1 \mathrm{ab} \\
(1.44)\end{array}$ & $\begin{array}{c}15.9 b c \\
(1.72)\end{array}$ & $\begin{array}{c}26.1 \mathrm{a} \\
(2.82)\end{array}$ & 26.5a (2.86) \\
\hline \multirow[t]{2}{*}{ NDF } & $\begin{array}{l}26.3 \mathrm{~b} \\
(1.65)\end{array}$ & $\begin{array}{l}26.5 b \\
(1.66)\end{array}$ & 26.4b (1.65) & $\begin{array}{l}28.8 \mathrm{ab} \\
(1.80)\end{array}$ & $\begin{array}{l}30.9 a \\
(1.93)\end{array}$ & $\begin{array}{c}28.8 \mathrm{ab} \\
(1.80)\end{array}$ \\
\hline & \multicolumn{6}{|c|}{ Parameter C } \\
\hline Whole & $\begin{array}{c}2.51 \mathrm{a} \\
(0.071)\end{array}$ & $\begin{array}{c}2.48 \mathrm{a} \\
(0.070)\end{array}$ & $\begin{array}{l}2.29 \mathrm{bc} \\
(0.065)\end{array}$ & $\begin{array}{l}2.40 \mathrm{ab} \\
(0.068)\end{array}$ & $\begin{array}{c}2.21 \mathrm{c} \\
(0.063)\end{array}$ & $\begin{array}{c}2.13 c \\
(0.060)\end{array}$ \\
\hline NDF & $\begin{array}{c}3.30 \\
(0.172)\end{array}$ & $\begin{array}{c}3.57 \\
(0.186)\end{array}$ & $3.57(0.186)$ & $3.55(0.185)$ & $\begin{array}{c}3.33 \\
(0.173)\end{array}$ & $3.41(0.177)$ \\
\hline
\end{tabular}

ALF, alfalfa; BFT, birdsfoot trefoil; CMV, cicer milkvetch; SNF, sainfoin; MBG, meadow bromegrass; SMB, small burnet.

Data are the means of three laboratory runs and three replicates within each run; standard errors in parentheses. 
Values within a row followed by the same letter are not different at $p<0.05$ based on the TukeyKramer multiplicity adjustment. 

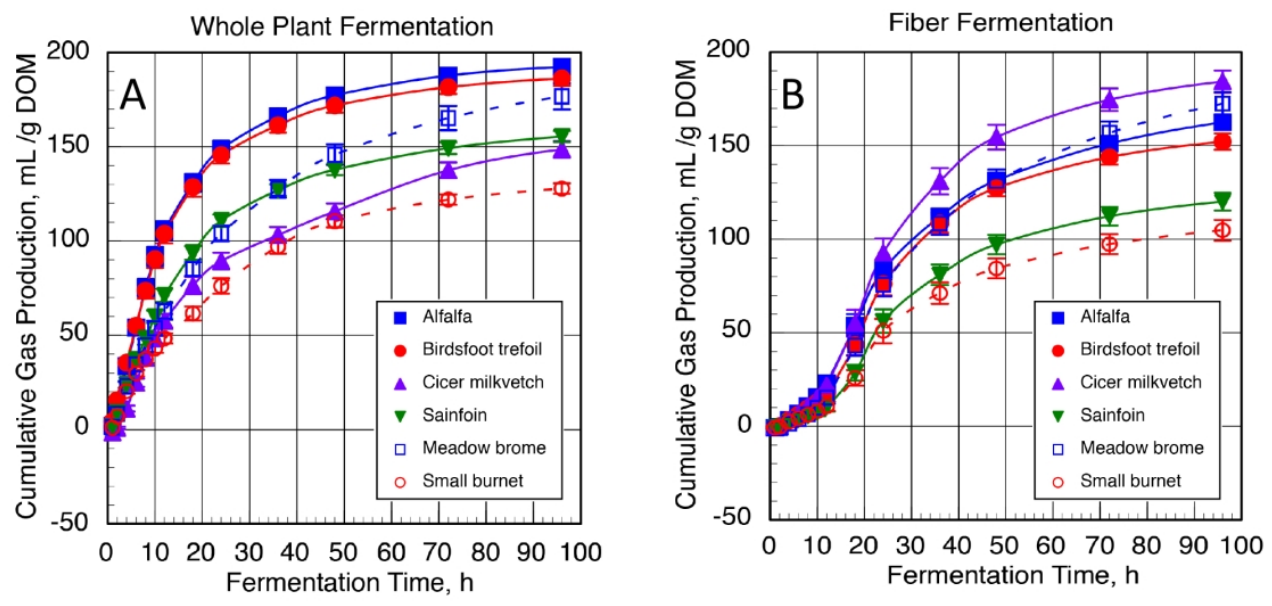

This article is protected by copyright. All rights reserved. 